\title{
Regenerating Adventitious Shoots from in Vitro Culture of Liatris spicata (L.) Willd. Cotyledons
}

\author{
Dennis P. Stimart ${ }^{1}$ and John C. Mather ${ }^{2}$ \\ Department of Horticulture, University of Wisconsin, Madison, WI 53706
}

Additional index words. blazing star, gayfeather, micropropagation, organogenesis, propagation

Abstract. Cotyledons from developing 6- to 8-week-old embryos of Liatris spicata (L.) Willd. (blazing star) were cultured on Murashige and Skoog medium containing 0, 0.4, 4.4, or $44.4 \mu_{\mathrm{M}}$ BA or $0,0.2,2.2$, or $22.2 \mu_{\mathrm{M}} \mathrm{TDZ}$ to induce adventitious shoot formation. The highest percentage of cotyledons forming the most shoots was on medium containing 2.2 $\mu_{\mathrm{M}}$ TDZ. Cotyledon-derived callus cultured on medium containing $4.4 \mu_{\mathrm{M}} \mathrm{BA}$ formed $\approx 16$ times more adventitious shoots than on $2.2 \mu \mathrm{M}$ TDZ. Adventitious shoots derived from cotyledons or callus produced roots when placed on MS medium containing 5.0 $\mu_{\mathrm{M}}$ IBA. Regenerated plants that flowered in the field appeared homogeneous. Chemical names used: $\mathrm{N}^{6}$-benzyladenine (BA), thidiazuron (TDZ), indole-3-butyric acid (IBA).

Liatris spicata, commonly known as blazing star or gayfeather (Asteraceae), is native to the eastern and midwestern United States. The attractive, upright, flowering stems produced from a perennial woody corm (Zieslin, 1985) are recognized as an important cut flower in several countries (Brown et al., 1982; Waithaka and Wanjao, 1982; Zieslin and Geller, 1983a, 1983b).

Blazing star propagates rapidly from axillary bud proliferation through micropropagation by treating stem pieces from expanding spikes with BA (Stimart and Harbage, 1989). Proliferated shoots that rooted after IBA treatment grew well when potted and in the greenhouse.

Producing plants in vitro serves as a method of rapid propagation and allows the possibility of their genetic manipulation. Development of such a system depends on efficient regeneration of plants from plant tissue or callus. Studies within Asteraceae have shown that zygotic embryos and cotyledons form adventitious shoots (Finer, 1987; Hammett andEvans, 1985; Stieve and Stimart, 1992). We describe regeneration of adventitious shoots from blazing star cotyledons and callus.

\section{Materials and Methods}

Seeds of Liatris spicata were extracted from flower heads in Sept. 1993, 6 to 8 weeks after pollination. They were stirred for $15 \mathrm{~min}$ in 5\% $\mathrm{NaOCl}$ (Clorox; Clorox Co., Oakland, Calif.) with 1 drop Tween 20/liter and rinsed

\footnotetext{
Received for publication 3 July 1995 . Accepted for publication 9 Nov. 1995. Use of trade names does not imply endorsement of the products named nor criticism of similar ones not named. The cost of publishing this paper was defrayed in part by the payment of page charges. Under postal regulations, this paper therefore must be hereby marked advertisement solely to indicate this fact.

${ }^{1}$ Professor.

${ }^{2}$ Research Program Manager II.
}

three times in sterile water. Embryos were excised from seeds with the aid of a dissecting microscope in a laminar air flow cabinet. Cotyledons were detached from the embryos. The proximal one-third of each cotyledon was excised and discarded to eliminate the possibility that the shoot apex was attached. The distal two-thirds of the cotyledon served as the explant source. Plants from which embryos were extracted were cloned by crown division for use as controls in field evaluation.

Basal culture medium consisted of Murashige and Skoog (MS) salts (Murashige and Skoog, 1962) supplemented with $0.56 \mathrm{~mm}$ myo-inositol, $1.2 \mu \mathrm{m}$ thiamine $\mathrm{HCl}$, and $88 \mathrm{~mm}$ sucrose. The medium was adjusted to a $\mathrm{pH}$ of 5.6 and was gelled with $7 \mathrm{~g}$ Difco Bacto agar/ liter. GA-7 containers with $75 \mathrm{ml}$ of medium were autoclaved $20 \mathrm{~min}$ at $120 \mathrm{C}$ at $104 \mathrm{kPa}$.

Cultures were maintained in a growth chamber at $25 \mathrm{C}$ under cool-white fluorescent light $\left(30 \mu \mathrm{mol} \cdot \mathrm{m}^{-2} \cdot \mathrm{s}^{-1}\right)$ from 0800 to $2400 \mathrm{HR}$ and in darkness from 2400 to $0800 \mathrm{HR}$. All experimental treatments were arranged in completely random designs.

Cotyledons were cultured on MS medium supplemented with $0,0.4,4.4$, or $44.4 \mu \mathrm{M}$ BA or $0,0.2,2.2$, or $22.2 \mu \mathrm{M}$ TDZ. These treatments were established based on observations from a preliminary study done in Aug. 1993 (data not presented). Cotyledons were placed on the medium surface and were subcultured to fresh medium of the same treatment after 3 weeks. Six weeks after the explants were made, data were collected on the number of cotyledons forming adventitious shoots, the percentage of cotyledons forming shoots, and the number of shoots per cotyledon. An adventitious shoot was counted only after it had developed a whorl of at least three to four leaves $\geq 10$ $\mathrm{mm}$ long and assumed the morphology of an organized shoot. Fifteen replications were used per treatment.

After 6 weeks, callus pieces 1 to $2 \mathrm{~mm}$ in diameter were removed from the cotyledons in the BA and TDZ treatments mentioned. These pieces were subcultured every 3 weeks on MS medium containing $2.2 \mu \mathrm{M}$ TDZ. Callus pieces subsequently subcultured were 2 $\mathrm{mm}$ in diameter. Adventitious shoot regeneration was determined following two subcultures at 3-week intervals on medium with 4.4 $\mu_{\mathrm{M}}$ BA or $2.2 \mu_{\mathrm{M}}$ TDZ. Treatments selected were based on preliminary studies of adventitious shoot count and shoot quality. Data were collected on the number of callus pieces forming adventitious shoots and the number of shoots per regenerating callus piece. An adventitious shoot was counted based on the criteria previously described. Ten replications were used per treatment with eight samples per replication. A sample consisted of a callus piece $\approx 2 \mathrm{~mm}$ in diameter.

Adventitious shoots were rooted in vitro in MS medium with 5.0 $\mu \mathrm{M}$ IBA (Stimart and Harbage, 1989). Rooted plants were transplanted into a 1 soil : 1 sand : 1 sphagnum peat (by volume) medium, acclimatized in the greenhouse, and transplanted to the field. A total of 73 plants were grown in the field through flowering the next season and were observed for aberrant phenotypes. Analyses of variance were performed, and treatment means were separated by least significant difference (SAS Institute, 1990).

\section{Results}

The percentage of cotyledons forming adventitious shoots and the number of adventitious shoots formed per cotyledon were higher on medium supplemented with TDZ at 2.2 or $22.2 \mu \mathrm{M}$ than in any other treatment (Table 1). The percent regeneration for the optimum treatment of $2.2 \mu \mathrm{M}$ TDZ was almost five times that for the best BA treatment $(0.4 \mu \mathrm{M})$. The former treatment also induced almost three times as many shoots per cotyledon as the latter treatment. Shoots failed to form on explants placed on medium without growth regulators or on medium containing $0.2 \mu \mathrm{M}$ TDZ or $44.4 \mu \mathrm{MBA}$. Shoots that formed on cotyledons growing in the presence of $22.2 \mu \mathrm{M} \mathrm{TDZ}$ were callus-like and vitreous.

The percentage of callus pieces forming

Table 1. Percentage of Liatris spicata cotyledons forming adventitious shoots and average number of adventitious shoots formed on cotyledons of excised embryos treated with various concentrations of BA and TDZ.

\begin{tabular}{lcl}
\hline $\begin{array}{l}\text { Growth } \\
\text { regulator } \\
(\mu \mathrm{M})\end{array}$ & $\begin{array}{c}\text { Cotyledons } \\
\text { regenerating } \\
\text { shoots }(\%)\end{array}$ & $\begin{array}{c}\text { Shoots/ } \\
\text { cotyledon } \\
\text { (no.) }\end{array}$ \\
\hline $\mathrm{BA}$ & 0 & $0 \mathrm{C}^{\mathrm{z}}$ \\
0 & 13 & $1.1 \mathrm{BC}$ \\
0.4 & 13 & $0.2 \mathrm{BC}$ \\
4.4 & 0 & $0 \mathrm{C}$ \\
44.4 & & \\
TDZ & 0 & $0 \mathrm{C}$ \\
0 & 0 & $0 \mathrm{C}$ \\
0.2 & 60 & $3.8 \mathrm{~A}$ \\
2.2 & 27 & $2.4 \mathrm{AB}$ \\
22.2 & & \\
\hline
\end{tabular}

${ }^{\mathrm{z}}$ Mean separation within column by least significant difference at $P \leq 0.05$.

yPlants callus-like and vitreous. 
adventitious shoots was about eight times higher in medium with BA than in medium with TDZ (Table 2). The number of adventitious shoots formed per callus piece was $\approx 16$ times higher on medium supplemented with BA than on that supplemented with TDZ (Table 2 and Fig. 1). Shoots induced by BA developed more elongated leaves than shoots induced by TDZ (data not presented).

A total of 73 plants derived from cotyledons or calli flowered in the field the following season. At flowering, all plants appeared morphologically homogeneous and similar to control plants.

\section{Discussion}

This study demonstrates that adventitious plants can be regenerated from Liatris spicata cotyledons or callus derived from cotyledons. The optimum treatment to induce adventitious shoot formation on cotyledons ( $2.2 \mu \mathrm{M}$ TDZ) was not the best one to promote adventitious shoots on callus ( $4.4 \mu \mathrm{M}$ BA). Also, with 4.4 $\mu \mathrm{M}$ BA, improvement in adventitious shoots formed on callus tissue was 25 -fold that on cotyledon tissue. This result indicates a difference in growth regulator requirements between cotyledon tissue and callus derived from cotyledon tissue. In comparable studies on other members of the Asteraceae, $31 \%$ of Helianthus annuus L. zygotic embryos formed adventitious shoots on medium containing 2,4dichlorophenoxyacetic acid (Finer, 1987); Centaurea junoniana Svent. produced 5.2 shoots per cotyledon on medium containing naphthalene acetic acid and BA (Hammatt and Evans, 1985); and Zinnia marylandica D.M. Spooner,

Table 2. Percentage of Liatris spicata callus pieces forming adventitious shoots and number of adventitious shoots formed on callus pieces when treated with optimal concentrations of BA or TDZ after 27 weeks of subculture.

\begin{tabular}{lcc}
\hline $\begin{array}{l}\text { Growth } \\
\text { regulator } \\
\text { and }\end{array}$ & $\begin{array}{c}\text { Callus pieces } \\
\text { regenerating } \\
\text { shoots } \\
\text { concn }(\mu \mathrm{m})\end{array}$ & $\begin{array}{c}\text { Shoots/ } \\
\text { callus } \\
\text { piece } \\
(\text { no. })\end{array}$ \\
\hline $\mathrm{BA}, 4.4$ & 78 & $4.9 \mathrm{~A}^{\mathrm{z}, \mathrm{y}}$ \\
$\mathrm{TDZ}, 2.2$ & 9 & $0.3 \mathrm{~B}$
\end{tabular}

${ }^{\mathrm{z}}$ Mean of 10 replications with eight samples per replication.

y Mean separation within column by least significant difference at $P \leq 0.05$.
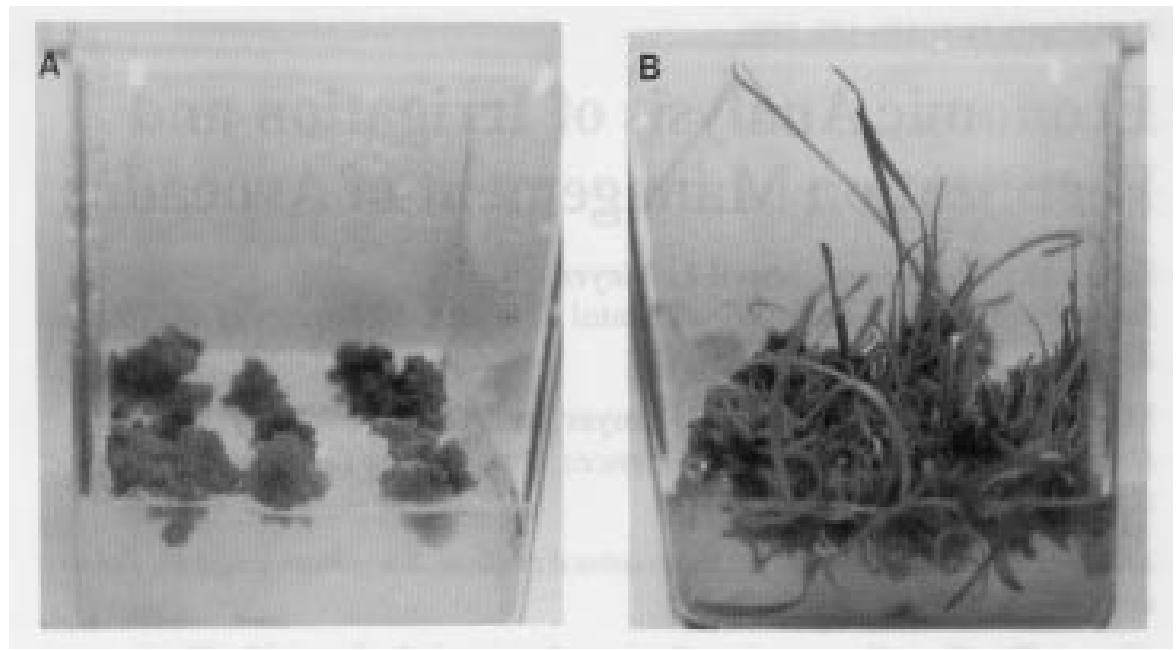

Fig. 1. Liatris spicata tissue cultures. (A) Callus on MS medium supplemented with $2.2 \mu_{\mathrm{M}}$ TDZ. (B) Adventitious shoot formation from callus on MS medium supplemented with $4.4 \mu \mathrm{M}$ BA.

D.P. Stimart, \&T.H. Boyle produced 7.5 shoots per cotyledon on medium containing TDZ (Stieve and Stimart, 1991). These results demonstrate that an array of plant growth regulators can successfully induce adventitious shoot formation on excised tissue from members of the Asteraceae. Using different growth regulators or timing of embryo extractions (Stieve and Stimart, 1991) are approaches that could expand knowledge on the adventitious shoot formation of blazing star.

Although being adventitious in origin, our plants flowered and appeared phenotypically normal. This result suggests genetic stability; however, its confirmation requires analysis of seed-derived progeny of the original adventitious plants. The phenotypic stability of seedderived plants from plants originally derived from in vitro methods requires investigation.

The regeneration techniques developed in this study could be useful in plant transformation of this species. Delivery of genes of interest into cells of cotyledons or callus, followed by selection of transformed cells and adventitious shoot recovery, may allow for introduction of novel genes.

\section{Literature Cited}

Brown, W.A., S.S. Salac, and J.B. Fitzgerald. 1982. Wildflower research aims at commercial use. Farm, Ranch \& Home Quart. 28:22-23.
Finer, J.J. 1987. Direct somatic embryogenesis and plant regeneration from immature embryos of hybrid sunflower (Helianthus annuus L.) on high sucrose-containing medium. Plant Cell Rpt. 6:372-374.

Hammatt, N. and P.K. Evans. 1985. The in vitro propagation of an endangered species: Centaurea junoniana Svent. (Compositae). J. Hort. Sci. 60:93-97.

Murashige, T. and F. Skoog. 1962. A revised medium for rapid growth and bioassays with tobacco tissue cultures. Physiol. Plant. 15:473497.

SAS Institute. 1990. SAS/STAT users guide, Version 6.09. 4th ed. vol. 2. SAS Inst., Cary, N.C.

Stieve, S.M. and D.P. Stimart. 1991. Zinnia marylandica tissue-culture induced variation and heritability. Acta Hort. 336:389-398.

Stimart, D.P. and J.F. Harbage. 1989. Shoot proliferation and rooting in vitro of Liatris spicata. HortScience 24:835-836.

Waithaka, K. and L.W. Wanjao. 1982. The effect of duration of cold treatment on growth and flowering of Liatris. Scientia Hort. 18:153-158.

Zieslin, N. 1985. Liatris, p. 287-291. In: A.H. Halevy (ed.). Handbook of flowering. CRC Press, Boca Raton, Fla.

Zieslin, N. andZ. Geller. 1983a. Studies with Liatris spicata Willd.: I. Effect of temperature on sprouting, flowering and gibberellin content. Ann. Bot. 52:849-853.

Zieslin, N. and Z. Geller. 1983b. Studies with Liatris spicata Willd.: II. Effect of photoperiod on stem extension, flowering and gibberellin content. Ann. Bot. 52:855-859. 